\title{
RESEARCH OF DEPENDENCE OF THE DAMAGE AREA ON TOW WIDTH ON FILAMENT-WOUND COMPOSITE TUBES
}

\author{
Marcelina Bobrowska*, Michą Barcikowski ${ }^{* *}$, RadosŁaw Rybczyński ${ }^{* *}$ \\ * Center for Composite Technologies, Institute of Aviation, al. Krakowska 110/114, 02-256 Warsaw, Poland, \\ ** Department of Mechanics, Materials Science and Engineering, Faculty of Mechanical Engineering, \\ Wroclaw University of Technology, ul. M. Smoluchowskiego 25, 50-370 Wrocław, Poland, \\ marcelina.bobrowska@ilot.edu.pl, michal.barcikowski@pwr.edu.pl, radoslaw.rybczynski@pwr.wroc.pl
}

\begin{abstract}
This paper explores the effect of tow width on the damage area produced by high velocity impacts on glass fiber/epoxy composite structures made by filament winding. The subject of the research were a four-layered composite tubes that have been designed using matrix method. The method was used to select mosaic patterns with different rest of the winding stroke and number of interlaces, which are places of stress concentration and which affect the strength of the composite. The narrowest $(5 \mathrm{~mm})$ and the widest $(17 \mathrm{~mm})$ tow width available was chosen. Composite filament-wound structures were subjected to a high velocity impact by a $2.0 \mathrm{~g}$ spherical hardened steel impactor propelled to a velocity of $140 \div 170 \mathrm{~m} / \mathrm{s}$ using a gas gun. It was observed that dependence of the damage area on tow width on filament-wound composite tubes is possible.

Keywords: Filament-wound composite structures, impact damage, ballistic impact, filament winding.
\end{abstract}

\section{INTRODUCTION}

Composites used in production of modern lightweight structures in aeronautic [1], automotive and marine engineering need to exhibit high specific stiffness and specific strength. The proper answer for these needs are fiber reinforced composites made using filament winding. Filament-wound cylinders are especially attractive for marine underwater applications [2].

Composite pressure vessels, just like composite filament-wound pipes, are made using filament winding. These method consists in winding continuous fiber roving onto a rotating mandrel in predetermined patterns [3]. Mosaic patterns, applied in filament winding, can be selected using an array method, designed by Wojciech Błażejewski. This method, among else, is used in composite pressure vessels design. In different mosaic patterns, sequence of bundle placement differs which results in the number of crossovers. The crossovers should be avoided as places of stress concentration affecting the strength of the composite [4].

Sub-ballistic or in other words intermediate-velocity impact, especially common in aviation, is characterized by velocity between 10 and $100 \mathrm{~m} / \mathrm{s}$. Time of impact is short, so that the elastic waves (both longitudinal and transverse) propagating in the material are not able to reach the edge of the impacted object during the stroke [5]. High-velocity impact, also called ballistic impact, is characterized by velocity of several hundred $\mathrm{m} / \mathrm{s}$. Even shorter - than in the case of sub-ballistic 
impact - time of stress wave propagation through the material is too short and the structure does not have time to respond - damage is confined to a small area around the point of impact. Both of mentioned impacts can be exercised with the use of a gas gun [6].

Damage mechanism and response to an impact are complex. Main parameters considered in impact classification are: impact velocity, impact angle, impactor geometry and its mass, as well as shape and mass of the impacted object. According to Abrate, impact velocity is particularly important [7].

Cone formation on the back face of the target, fiber failure (in the form of fracture of primary fibers or deformation of secondary yarns), delamination, matrix cracking, shear plugging and friction between the projectile and the target, as well as the reinforcement architecture can influence the energy absorbing mechanisms [8].

In recent years most of research of impact resistance of composite structures made using filament winding has been concerned with low-velocity impacts $[9,10]$. Ballistic impact damage results presented in this paper cannot be compared to results from the literature concerning low-velocity impacts.

\section{SELECTION OF MOSAIC PATTERNS}

Array method allows to generate several kinds of weaves - mosaic patterns - with objective to obtain a regular layer. Winding angle $\alpha$ is the most important geometric parameter, directly related to stress distribution in pressure vessels as described in following equation:

$$
\frac{\sigma_{o}}{\sigma_{w}}=(\tan \alpha)^{2}
$$

where: $\sigma_{o}$ - circumferential stresses, $\sigma_{w}$ - longitudinal stresses.

Mosaic pattern condition is fulfilled only when the core is completely covered with a uniform layer of saturated roving beams. Otherwise, gaps and inequalities occur. Proper selection of mosaic pattern involves determining the optimal distribution of crossovers that become the sites of stress concentration and fracture initiators [11].

For average thickness of wound structures set to approx. $4 \mathrm{~mm}$, calculated number of layers correspond to 11 . Following winding parameters were established: tow width -5 and $17 \mathrm{~mm}$, winding angle $\alpha=54.7^{\circ}$, core diameter $d=110 \mathrm{~mm}$ (constant over the entire length); these were the starting point for necessary calculations (Tab. 1).

Tab. 1. Calculated parameters used to generate array for 13 tows

\begin{tabular}{|l|c|c|}
\hline Calculated parameters & $e=5 \mathrm{~mm}$ & $e=17 \mathrm{~mm}$ \\
\hline Tow width, $e_{x}=\frac{e}{\cos \alpha}, \mathrm{mm}$ & 8.65 & 29.42 \\
\hline Tow number, $Z=\frac{2 \pi r}{e_{x}}, \mathrm{~mm}$ & 40 & 12 \\
\hline Winding lead, $s=\frac{\pi d}{\tan \alpha}, \mathrm{mm}$ & 244.68 & 244.68 \\
\hline Nominal cover rate, $C \%=\frac{Z \cdot e_{x}}{\pi d} \cdot 100 \%$ & 100.15 & 102.21 \\
\hline Modified cover rate, $C^{\prime} \%=\frac{(Z+1) \cdot e_{x}}{\pi d} \cdot 100 \%$ & 102.66 & 110.67 \\
\hline
\end{tabular}




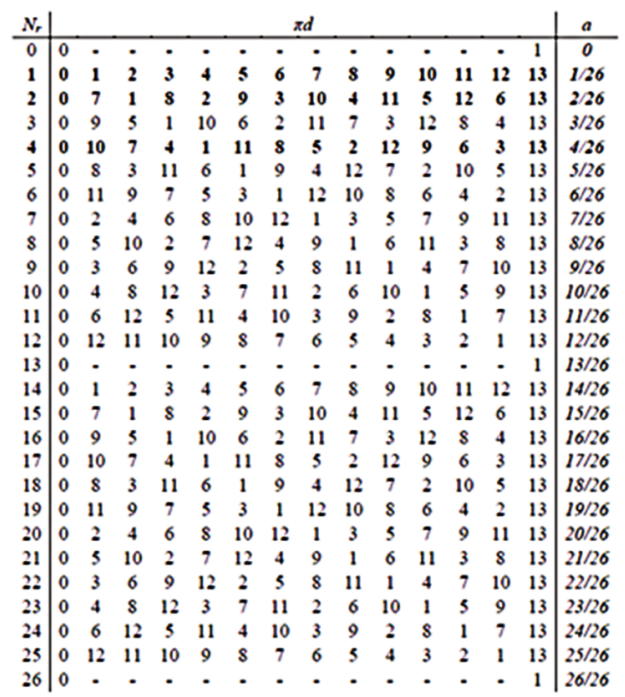

Fig. 1. „Table 13” (13 circumference bundles), $N_{r}$-type of layer, $\pi d$ - bundles order on the circumference, value of $a$-rest of winding lead coefficient, $a \in(0,1)$

Number of tows $Z$ was increased by 1 and amounted 13 and 41 tows respectively, so that for last wound layer the cover ratio would be at least $100 \%$. In addition odd number of tows ensures almost $100 \%$ cover rate.

An array for 13 tows was generated using calculated parameters (Fig. 1). For this study, two mosaic patterns were chosen: $N_{r} 1$ with the least and $N_{r} 2$ with the largest number of crossovers. For each matrix with a natural number greater than 1 , both $N_{r} 1$ and $N_{r} 2$ mosaic pattern exists regardless of number of tows.

Manual generation of array for 41 tows is too time-consuming so it was decided to use Nawijarka v2.2 software to generate all mosaic patterns possible to wind. The $N_{r} 2$ mosaic pattern from matrix 41 is displayed in Fig. 2. ComposicaD software was used to generate three-dimensional view of tubes with first five tows wound. Mosaic pattern $N_{r}$ from matrix 41 is illustrated in Fig. 3.

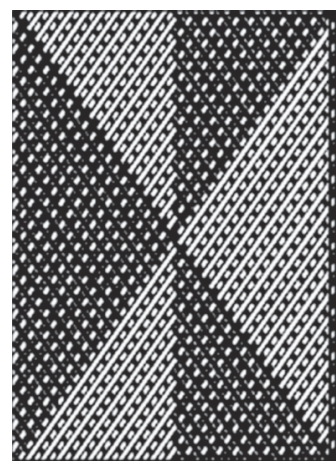

Fig. 2. $N_{r} 2(5 \mathrm{~mm})$ mosaic pattern scheme

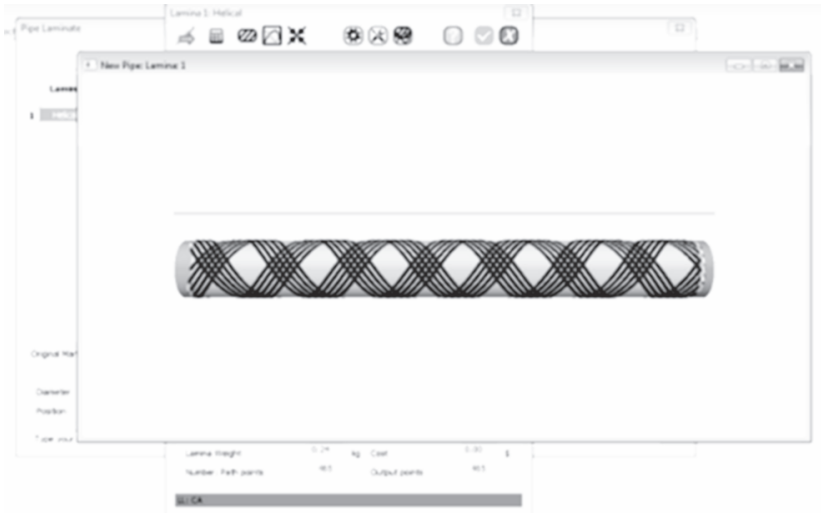

Fig. 3. Three-dimensional illustration of $N_{r} 2$ mosaic pattern (tow width $5 \mathrm{~mm}$ ) 


\section{MATERIALS USED IN FILAMENT-WINDING}

All composites for this research were prepared using E-glass fiber roving reinforcement ER $3005 / 1200 / 10$. The diameter of the filament is $10 \div 15 \mu \mathrm{m}$. Roving is soft, mostly used as reinforcement for epoxy resins in filament winding or pultrusion.

The composition used to manufacture all of tested composites was Epolam 5015 epoxy resin and Epolam 2016 hardener, produced by Axson. The resin and hardener were mixed in a weight ratio 100:36. Variable reactivity, very good wettability of the fibers, no foaming and resistance to moist environment are significant advantages of applied mixture. Moreover, this combination of resin and hardener allows long-duration winding, which is important in laboratory conditions, especially for winding thin beams.

Prepared samples were stored at $20^{\circ} \mathrm{C}$ for 24 hours and then cured at $70{ }^{\circ} \mathrm{C}$ for 12 hours according to the technical sheet.

Average thickness of each sample and other characteristic parameters of composite tubes was included in Tab. 2.

Views of the actual structures and their graphic illustrations are shown in Fig. 4.

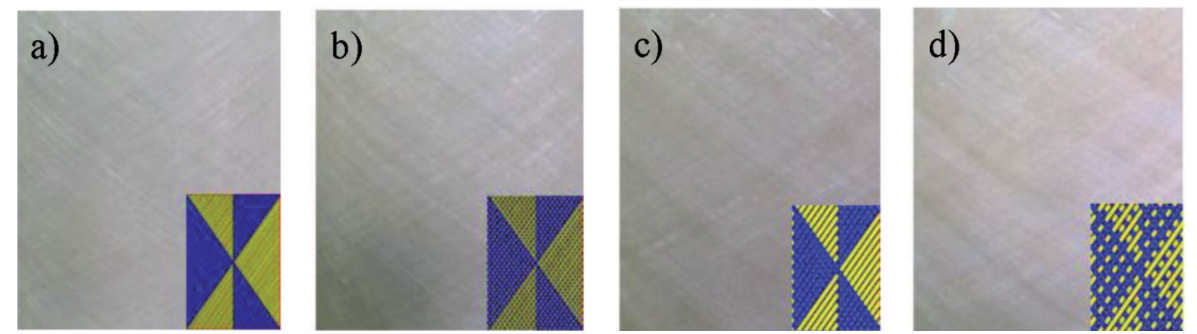

Fig. 4. Views of the actual structures and their graphic illustrations: $\mathrm{a}-N_{r} l(5 \mathrm{~mm}) ; \mathrm{b}-N_{r} 2(5 \mathrm{~mm})$; $\mathrm{c}-N_{r} l(17 \mathrm{~mm}) ; \mathrm{d}-N_{r} 2(17 \mathrm{~mm})$ [Author, 2015]

Tab. 2. Parameters of manufactured structures [Author, 2015]

\begin{tabular}{|c|c|c|c|c|c|}
\hline $\begin{array}{l}\text { Mosaic } \\
\text { pattern }\end{array}$ & $\begin{array}{l}\text { Structure number (ac- } \\
\text { cording to array table) }\end{array}$ & $\begin{array}{c}\text { Tow width } \\
e, \mathrm{~mm}\end{array}$ & $\begin{array}{l}\text { Number of } \\
\text { crossovers }\end{array}$ & $\begin{array}{c}\text { Sample } \\
\text { thickness, mm }\end{array}$ & $\begin{array}{l}\text { Thickness } \\
\text { aspect ratio }\end{array}$ \\
\hline$N_{r} l$ & 1 & 5 & 360 & 4.20 & \multirow{2}{*}{1.39} \\
\hline$N_{r} l$ & 1 & 17 & 96 & 5.84 & \\
\hline$N_{r} 2$ & 2 & 5 & 3360 & 4.34 & \multirow{2}{*}{1.45} \\
\hline$N_{r} 2$ & 2 & 17 & 336 & 6.31 & \\
\hline
\end{tabular}

\section{IMPACT TEST}

The composite tubes were subjected to ballistic impact using a compressed-air gun test assembly (Fig. 5). The gas gun propels an impactor in the form of hardened steel ball $7.86 \mathrm{~mm}$ in diameter and $2.0 \mathrm{~g}$ in weight, by means of compressed air stored in a tank. Velocity of the free-flying impactor was measured by ballistic chronograph (Fig. 6b).

A specimen holder (Fig. 6a) designed for test purposes enables precise vertical and horizontal positioning of the specimen so that the impactor strikes perpendicular to the lateral surface of the cylinder. Specimens were fixed to the specimen holder using two flexible bands.

Each specimen was subjected to ballistic impact four times, rotating the specimen by $90^{\circ}$ after each impact. The first point always corresponded to crossovers of the fibers in the last layer.

The tests contained velocities in the range of $144 \div 172 \mathrm{~m} / \mathrm{s}$, resulting in impact energies in the range of $21 \div 30 \mathrm{~J}$ (Tab. 3). 


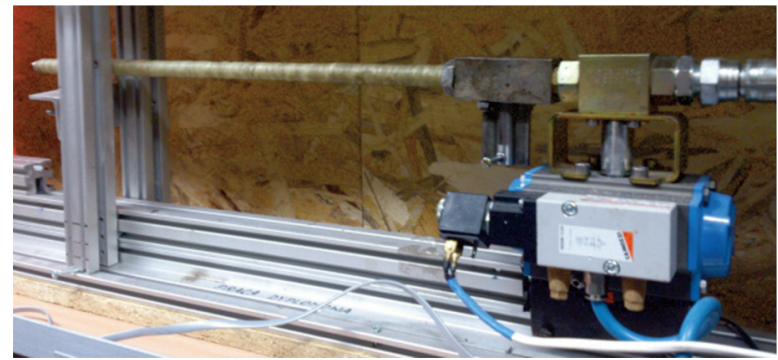

Fig. 5. Gas gun - propelling part [Author, 2015]

a)

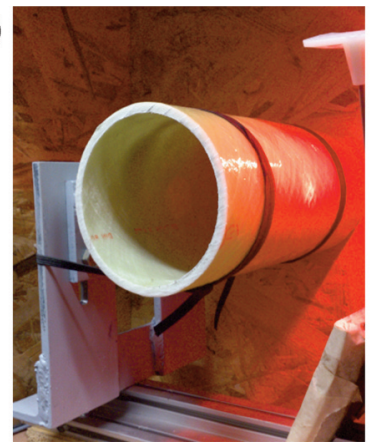

b)

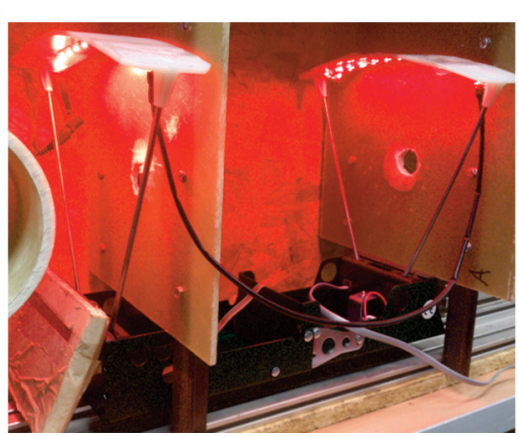

Fig. 6. Fixing and measuring part: $\mathrm{a}-$ specimen holder; $\mathrm{b}-$ measuring assembly [Author, 2015]

Tab. 3. Velocity and kinetic energy of the impactor [Author, 2015]

\begin{tabular}{|c|c|}
\hline Impactor velocity, m/s & Impactor energy, J \\
\hline $143.7 \pm 1.2$ & $20.65 \pm 0.35$ \\
\hline $159.5 \pm 1.2$ & $25.43 \pm 0.37$ \\
\hline $172.4 \pm 1.3$ & $29.71 \pm 0.45$ \\
\hline
\end{tabular}

\section{MEASUREMENT OF THE DAMAGE AREA AS VISIBLE IN TRANSMITTED LIGHT}

Fig. 7 presents damage areas after impact $30 \mathrm{~J}$, visible in daylight. Front face delamination area is smaller than back face delamination area, consistent with the pine tree-shaped delamination interfaces increase through the thickness of the laminate [6].

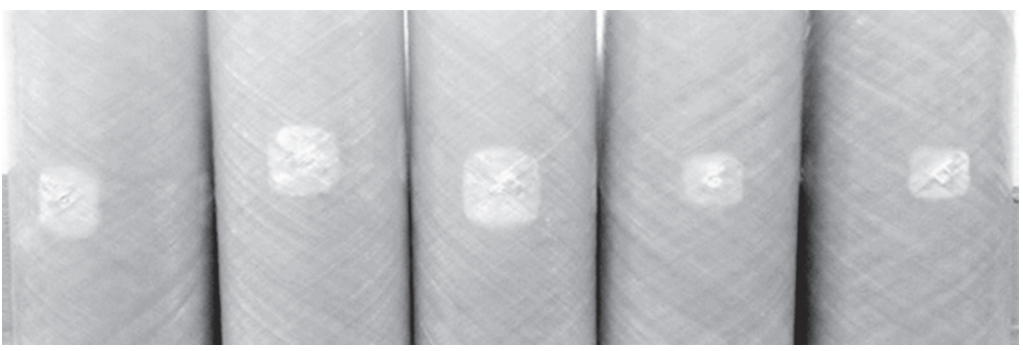

Fig. 7. Damage areas after impact 30 J, visible in daylight [Author, 2015] 
The extent of delamination was evaluated by means of digital image analysis. Because specimens were not flat, it was necessary to trace outlines of damage areas on a carbon paper pressed to cylindrical surfaces of the specimens. Obtained copies were scanned and images were processed using Scion Image software to measure the contrasting delaminated area.

Copies of delamination area of specimens for 1 impact point are shown in Fig. 8.

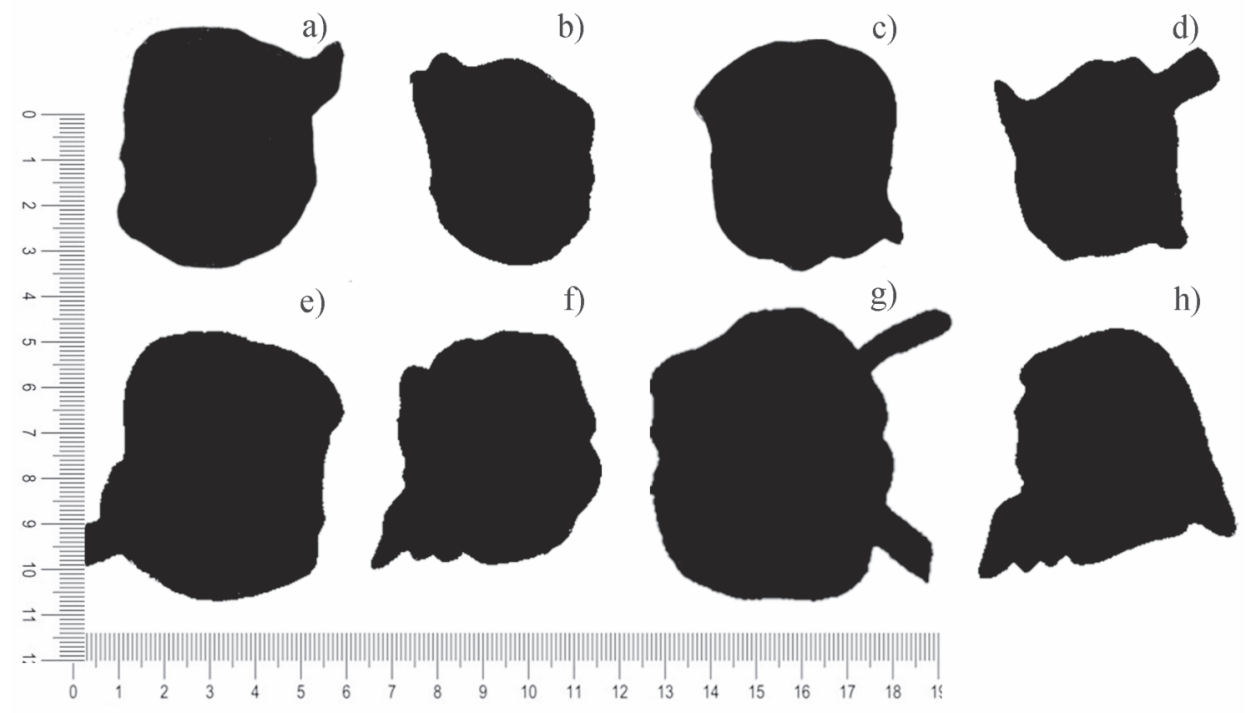

Fig. 8. Scanned copies of damage area of specimens after impact: a $-20 \mathrm{~J}, \mathrm{~N}_{\mathrm{r}} 1(5 \mathrm{~mm})$; $\mathrm{b}-20 \mathrm{~J}, \mathrm{~N}_{\mathrm{r}} 1(17 \mathrm{~mm}) ; \mathrm{c}-20 \mathrm{~J}, \mathrm{~N}_{\mathrm{r}} 2(5 \mathrm{~mm}) ; \mathrm{d}-20 \mathrm{~J}, \mathrm{~N}_{\mathrm{r}} 2(17 \mathrm{~mm}) ; \mathrm{e}-30 \mathrm{~J}, \mathrm{~N}_{\mathrm{r}} 1(5 \mathrm{~mm}) ;$ $\mathrm{f}-30 \mathrm{~J}, \mathrm{~N}_{\mathrm{r}} 1(17 \mathrm{~mm}) ; \mathrm{g}-30 \mathrm{~J}, \mathrm{~N}_{\mathrm{r}} 2(5 \mathrm{~mm}) ; \mathrm{h}-30 \mathrm{~J}, \mathrm{~N}_{\mathrm{r}} 2(17 \mathrm{~mm})$ [Author, 2015]

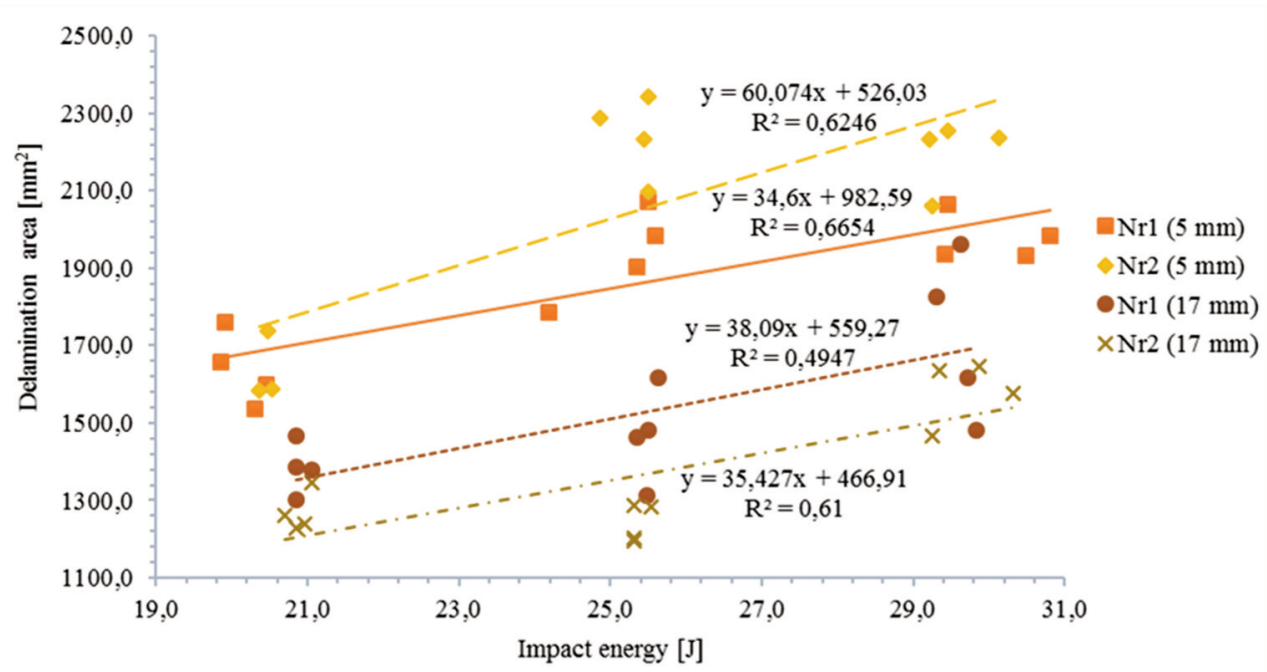

Fig. 9. Dependence of delamination area on impact energy [Author, 2015]

Dependence of the area of delamination on impact energy observed for all four tubes wasn't strictly linear, as presented in Fig. 9. It is important to remember that samples thickness were significantly different from each other. It could affect the difference of the delamination area after impact. 


\section{CONCLUSIONS}

Research of impact damage on filament-wound tubes is mainly concerned with low-velocity impact, confirmed by present literature. There is no possibility to compare it with the results from this study. Observation of impact damage surface allowed to draw following conclusions:

1. It was observed impact damage area increases in the range of $1194.49 \div 2342.18 \mathrm{~mm}^{2}$ with increasing impact velocity $(144 \div 172 \mathrm{~m} / \mathrm{s})$ independently on number of crossovers.

2. The most intensive increase on $\mathrm{X}$ axis was noticed for mosaic pattern $N_{r} 2(5 \mathrm{~mm})$. Coefficient $a$ (the slope) from the linear equation $\mathrm{y}=a x+b$ corresponded to 60 while for others structures it is close to 35. The greater the difference between thickness of sample wound with the same mosaic pattern but different tow width, the smaller the difference of area of delamination measured for points impacted with the similar velocity. For tubes wound with mosaic pattern $N_{r}$, the difference of delamination area for points impacted with similar velocity was greater than for tubes wound with mosaic pattern $N_{r} 1$. It is possible this effect is caused by bigger difference between thicknesses of tubes with structure $N_{r} 2$ than $N_{r} 1$.

3. Trend lines formed by linear equation $y=a x+b$ for impact points of tubes wound with different mosaic pattern but the same tow width are parallel. It means that for tubes wound with $17 \mathrm{~mm}$ tow width and different mosaic pattern the difference of delamination area for points impacted with similar velocity is stable independent on increasing the energy of impact. This dependence wasn't observed for tubes wound with narrower $(5 \mathrm{~mm})$ tow. For this tubes, the difference of delamination area was increasing for higher level of impact energy.

4. For all tubes there is no evidence confirming that the delamination area depends linearly on impact energy. None of linear correlation coefficient calculated individually for different points of impact were close to 1 .

5. It was not observed, that each subsequent impact would affect the total strength of tested tube. There was no difference between all areas of delamination resulting from impact for all impact points of each tube. The variance between impact damage volume for 1 and 4 impact point was in the range of $-230 \div 280 \mathrm{~mm}^{2}$ (minus means impact damage volume for impact point number 4 was smaller than for point 1 and plus respectively inversely).

6. Small fiber displacement, incomplete fibers saturation, as well as possibility of air pockets between layers are hard to avoid during filament winding process and adversely affect the strength of the composite. Impacting at one of this points of weakness could influence the results.

7. Damaged surfaces were measured using the simplest way - by their manually tracing and then digital analysis. Manually tracing the area delamination is always fraught with human eye error. Subjective view dependent on researcher can caused mistakes of about $2 \mathrm{~mm}$.

8. It is possible to improve the research by more accurate impact placement, or through devising other method (eg. a scanner) to accurately measure damaged surfaces. This procedures will improve their reliability and lead to better understanding of the mechanisms of impact damage on filament wound composite tubes.

\section{BIBLIOGRAPHY}

[1] Szeląg D., 2004, Institute of Aviation Activity in Design and Testing of Composite Structures, Prace Instytutu Lotnictwa, Numer Specjalny, pp. 51-62.

[2] Gninga P.B., Tarfaouia M., Collombetb F., Riouc L., Davies P., 2005, Damage development in thick composite tubes under impact loading and influence on implosion pressure: experimental observations, Composites: Part B, 36, pp. 306-318. 
[3] Abdalla F.H., Mutasher S.A., Khalid Y.A., Sapuan S.M., Hamouda A.M.S., Sahari B.B., Hamdan M.M., 2007, Design and fabrication of low cost filament winding machine, Materials and Design, 28, pp. 234-239.

[4] Błażejewski W., 2013, Kompozytowe zbiorniki wysokociśnieniowe wzmocnione włóknami wedtug wzorów mozaikowych, Oficyna Wydawnicza Politechniki Wrocławskiej, Wrocław.

[5] Barcikowski M., 2012, Wpływ materiałów i struktury laminatów poliestrowo-szklanych na ich odporność na udar balistyczny, Praca doktorska ZUT, Szczecin.

[6] Richardson M. 0. W., Wisheart M. J., 1996, Review of low-velocity impact properties of composite materials, Composites Part A, 27A, pp. 1123-1131.

[7] Abrate S., 1998, Impact on composite structures, Cambridge University Press, New York, ISBN 0-521-47389-6 (hc).

[8] Naik N.K., Shrirao. P., 2004, Composite structures under ballistic impact, Composite Structures, 66, pp. 579-590

[9] Perillo G., Grytten F., Sørbø S., Delhaye V., 2015, Numerical/experimental impact events on filament wound composite pressure vessel, Composites Part B, 69, pp. 406-417.

[10] Curtis J., Hinton M.J., Li S., Reid S.R., Soden P.D., 2000, Damage, deformation and residual burst strength of filament-wound composite tubes subjected to impact or quasi-static indentation, Composites Part B, 31, pp. 419-433.

[11] Błażejewski W., 1999, Wpływ struktury nawijania włókna na wytrzymałość elementów walcowych wykonanych z kompozytu epoksydowo-szklanego, Praca doktorska PWr, Wrocław.

\section{BADANIA ZALEŻNOŚCI PÓL USZKODZEŃ OD SZEROKOŚCI WIĄZKI NAWIJANEJ RUR KOMPOZYTOWYCH WYTWORZONYCH METODA NAWIJANIA WŁÓKNA NA MOKRO}

\section{Streszczenie}

Niniejszy artykuł stanowi charakterystykę wpływu szerokości nawijanej wiązki na wielkość pól uszkodzeń będących następstwem udaru wysokiej prędkości w szklano-epoksydowych konstrukcjach kompozytowych, wytworzonych metodą nawijania włókna na mokro. Badaniom poddano cztery warstwowe rury kompozytowe, nawinięte według wybranych wzorów mozaikowych, zaprojektowanych z użyciem metody tablicowej, różniących się wartością reszty skoku nawijania oraz liczbą przeplotów, będących miejscami koncentracji naprężeń i znacząco wpływających na wytrzymałość kompozytu. Wybrano dwie szerokości wiązki: najwęższą $(5 \mathrm{~mm})$ oraz najszerszą $(17 \mathrm{~mm})$ dostępne dla danej nawijarki. Badania udarności kompozytowych konstrukcji nawijanych przeprowadzono, strzelając w obiekt impaktorem w postaci ulepszonej cieplnie, stalowej kulki o masie 2.0 g napędzanej działem gazowym, z prędkością $140 \div 170 \mathrm{~m} / \mathrm{s}$. Stwierdzono, że szerokość nawijanego pasma może wpływać na wielkość pól uszkodzeń badanych kompozytów.

Słowa kluczowe: Kompozytowe konstrukcje nawijane, uszkodzenia udarowe, udar balistyczny, metoda nawijania. 